\title{
開口部を有する上向越流堰が河床変動および 流れの構造に与える影響
}

\author{
大本照憲 ${ }^{1} \cdot$ 宇根拓孝 ${ }^{2}$ \\ ${ }^{1}$ 正会員 工博 熊本大学教授 大学院自然科学研究科（二860-8555 熊本市中央区黒髪 2 丁目 39 番 1 号) \\ E-mail: ohmoto@kumamoto-u.ac.jp \\ 2 学生会員 熊本大学大学院自然科学研究科（同上） \\ E-mail:167d8807@st.kumamoto-u.ac.jp
}

\begin{abstract}
本研究では，開口部を有する上向越流堰において相対越流水深が堰下流の河床変動に与える影響および堰下流域に発 達した砂州の基本特性および河床上の流れの三次元構造について直角越流堰との比較を基に検討した. 実験結果から， 最大洗掘深および最大堆積厚は静的平衡河床においては上向きにおいて相対越流水深の増大に伴って指数関数的に減少 すること，さらに，上向き堰前面で発生した横断方向に軸を持つ馬蹄形渦は堰開口部を流下するに従って流下方向に軸 を持つ縦渦に向きを変え，その外側には逆回転の縦渦が形成することが見出された.
\end{abstract}

Key Words : upward weir with an opening, river bed morphology, local Scouring, sand bar, three-dimensional turbulent flow, cellular secondary currents

\section{1. はじめに}

ダムや堰などの河川横断構造物は川が本来有する連続 性を遮断，物理・生物環境の多様性を消失，さらに自然攪 乱を抑制する傾向を持つことが指摘されている．具体的に は生態系の劣化現象に対して, 横断構造物の下流における 流量・流砂量の減少，水温・水質の不連続性，濁水の長期 化, 横断構造物における上下流間での水生生物の移動阻害 が要因として挙げられる.

そのため，米国では堰を含めたダムの老朽化や河川環境 の劣化を改善するために既に 500 以上の堰やダムが撤去さ れている ${ }^{1)}$ ，また，側岸浸食の抑制，流砂の促進，魚類の 生息環境改善，河道の安定性，瀬と淵の創出のために Cross-Vane,W-Weir あるいはJ-Hook Vane の検討がされて (る2).

Dawei Guan ら ${ }^{3)}$ は, 堰下流における河床の洗掘形状, 流 れのパターンおよび乱流特性について議論し, 堰が横断方 向に一様な形状であっても堰下流には二次流が発生し，流 れの三次元構造が顕著に表れることを指摘した.

類似の局所流現象として橋脚や橋台，水制の局所洗掘 がある. Melville4) 橋脚や橋台に関する既往研究を取り 縓め, 極大洗掘深の経験式を提示している.

既往研究において開口部を有する堰が河床変動に与え
る影響について検討された事例は少ない.

Zhang ら ${ }^{5)}$ は，粒径や比重の異なる各種の路床材料を敷 きならした水路に開口部を有する種々の堰を設置し, 越流 状態における堰上流域における河床の洗掘特性や堰周辺 の局所流を検討した．また，住田らのは，アスペクト比の 比較的大きい実験水路を用い，堰開口部の形状や大きさが 堰上流の河床変動に与える影響, 洗掘に伴う流路の形成を 検討している．しかし，開口部を有する堰が堰下流域の河 床変動に与える影響については研究例が少なく, 開口部を 有する堰が下流域の河床の洗掘・堆積特性や流れに与える 影響についての研究事例は皆無に等しい.

加藤清正の時代に築造されたと言われる球磨川の遙拝 堰や菊池川の白石堰は，その平面形状から八の字堰と言わ れ，堰が側岸から上流に向きを取っていた．開口部は舟運 のために開かれたものであり, 遙拝堰においては堰の長さ は200間，開口部は 20 間であった.

著者等 7)は，静的平衡河床を対象に開口部を有する堰が 下流の河床変動に与える影響および堰下流域に発達した 砂州上の流れの三次元性について検討した. その結果，1) 開口部を有する堰周辺の洗掘は，開口部周辺に集中し，洗 掘の面的広がりおよび深さは相対越流水深の増加に従つ て小さくなる．2)堰上流域では堰開口部近傍において強い 下降流が現れ，堰下流域では砂州との位置関係が強く，砂 
州上では上昇流，砂州間の谷部において収束する下降流が 認められた. 3)堰前面で発生した横断方向に軸を持つ馬蹄 形渦は堰開口部を流下寸るに従って流下方向に軸を持っ 縦渦に向きを変え, その外側には逆回転の縦渦が形成され た.

本研究では, 開口部を有する上向越流堰において相対越 流水深が堰下流の河床変動に与える影響および堰下流域 に発達した砂州の基本特性および河床上の流れの三次元 構造について直角越流堰との比較を基に検討した.

\section{2. 実験装置および方法}

実験は全長 $10 \mathrm{~m}$, 幅 $\mathrm{B}=40 \mathrm{~cm}$, 高さ $20 \mathrm{~cm}$ のアクリル樹 脂からなる循環式可変勾配水路を用いて行った.

図-1 に示寸様に上流端から下流 $5 \mathrm{~m}$ の水路中央部に幅 $10 \mathrm{~cm}$ の開口部を有する堰を設置し，堰上流 $4.5 \mathrm{~m}$ 区間およ び下流側 $4.5 \mathrm{~m}$ 区間には相対越流水深に忘じて移動床厚を 一様な大きさ $(3 \mathrm{~cm}$ から $10.5 \mathrm{~cm}$ の範囲) で平均粒径 $1.7 \mathrm{~mm}$, 均等係数 1.50 の珪砂を敷き均した. 堰の向きは側岸の法線 を基準にして側岸に直角 $\left(\theta=0^{\circ}\right)$, 上向き $\left(\theta=10^{\circ}\right)$ および下向き $\left(\theta=-10^{\circ}\right)$ の 3 種である. 開口部の底面は 珪砂で構成され洗掘を許容している. なお, 堰上流側の河 床高は, 下流側の河床高に較べて $1 \mathrm{~cm}$ 高く設定した.

表-1 に移動床実験の条件を示寸. 本研究では, 静的平衡 河床を対象としているために堰の影響が及ばない上流域 および下流域で平均粒径の河床材料が掃流されない限界 掃流力以下の流量に設定した. なお, 相刘越流水深は, 越 流水深を堰高で除した值である.

実験は，相対越流水深に応じた河床高に砂を敷き均し， 一定の流量 $(Q=4.3 \ell / s)$ および水路勾配 $(I=1 / 500)$ の 基で下流端の堰操作を行い，何れのケースにおいても 24 時間以上通水の後に, 河床が平衡状態に達したことを確認 の上, 河床高を計測した. なお, 堰の局所洗掘の影響が及 ばない地点で断面平均流速が約 $10 \mathrm{~cm} / \mathrm{s}$ および $20 \mathrm{~cm} / \mathrm{s}$ にお いて相刘越流水深を系統的に変化させた. 表中の $U$ は堰よ り上流 $3 \mathrm{~m}$ 位置における断面平均流速, $H$ は越流水深, $D_{\mathrm{w}}$ は堰高, $H / D_{\mathrm{w}}$ は相対越流水深である. $K_{\mathrm{I}}$ は断面平均流速 U に対する河床材料の移動限界流速 $U_{\text {cr }}$ で Melville ${ }^{4}$ によっ て提示された $K$ ファクターの中の流れの強さに相当する.

座標系は開口部がある水路中央底面を原点とし, 流下方 向に $\mathrm{x}$ 軸，横断方向に $\mathrm{y}$ 軸，鉛直下向方向に $\mathrm{z}$ 軸をとり， 右手系とする. また，それぞれの流速成分を $u, v, w$, 時 間平均成分を $U, V, W$, 変動成分を $u^{\prime}, v^{\prime}, w^{\prime}$ と表す. 水 位および河床高の計測には，それぞれ，ポイントゲージお よび超音波水位計を用いた.

流動機構の検討は，表-1 の CaseU2-4において水面形， 流速の点計測および多点同時計測を行った. 表面流の計測

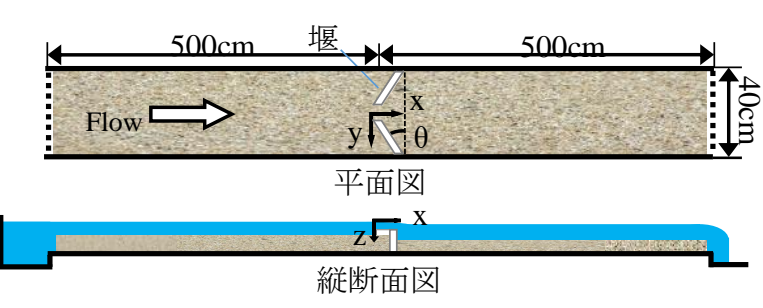

図-1 実験水路

表-1 実験条件

\begin{tabular}{|c|c|c|c|c|c|c|}
\hline 堰の向き & Case & $\mathrm{U}(\mathrm{cm} / \mathrm{s})$ & $\mathrm{K}_{1}$ & $\mathrm{H}(\mathrm{cm})$ & $\mathrm{D}_{\mathrm{w}}(\mathrm{cm})$ & $\mathrm{H} / \mathrm{D}_{\mathrm{w}}$ \\
\hline \multirow{6}{*}{ 上向き } & U2-1 & \multirow{12}{*}{20} & \multirow{12}{*}{0.47} & 1 & 4.5 & 0.22 \\
\hline & U2-2 & & & 1.5 & 4 & 0.38 \\
\hline & U2-3 & & & 2 & 3.5 & 0.57 \\
\hline & U2-4 & & & 2.5 & 3 & 0.83 \\
\hline & U2-5 & & & 2.8 & 2.8 & 1 \\
\hline & U2-6 & & & 3 & 2.5 & 1.2 \\
\hline \multirow{6}{*}{ 下向き } & D2-1 & & & 1 & 4.5 & 0.22 \\
\hline & D2-2 & & & 1.5 & 4 & 0.38 \\
\hline & D2-3 & & & 2 & 3.5 & 0.57 \\
\hline & D2-4 & & & 2.5 & 3 & 0.83 \\
\hline & D2-5 & & & 2.8 & 2.8 & 1 \\
\hline & D2-6 & & & 3 & 2.5 & 1.2 \\
\hline
\end{tabular}

には, 流速の多点同時計測が可能なビデオカメラを用いた PIV(Particle Image Velocimetry)法を，流速の点計測にはI 型 およびL型の電磁流速計を用いた. PIV 法による流速の計 測においては水路真上から表面流の撮影を行い, 流速の計 測時間は 20 秒，トレーサーとして粒径 $100 \mu \mathrm{m}$ ，比重 1.02 のナイロン粒子を使用した. 可視化画像はフレームレイト 59.94fps(frame per second), 1920×1080（pixel）のモノクロ ビデオ画像としてパーソナルコンピュータのハードディ スクに記録し，PIV 法によって処理された．また，電磁流 速計の出力信号は $100 \mathrm{~Hz}$ で, $\mathrm{AD}$ 変換した後 1 測点 4,096 個のデータに関して統計処理が施された.

\section{3. 実験結果}

\section{（1）静的平衡河床形状}

図-2および3 は，それぞれ，断面平均流速が $20 \mathrm{~cm} / \mathrm{s}$ に おける上向き堰および下向き堰の河床洗掘・堆積形状のコ ンターを示寸. なお, コンターの数值は初期平坦河床から 変化量を $\mathrm{mm}$ 単位で表示した.

上向き堰および下向き堰における洗掘は, 堰開口部周辺 に集中し, 洗掘の面的広がりおよび深さは相対越流水深 $H / D_{\mathrm{W}}$ の増加に従って小さくなる. また, 洗掘幅は堰下流 に較べ，上流側で大きくなる. 上向き堰と下向き堰との比 較では洗掘の面的広がりは上向き堰の方が大きい. 堰先端 部の馬蹄形渦に伴う下降流位置で局所洗掘が大きくなる ことが推察される. 
$\begin{array}{llllllll}40 & 20 & 0 & -20 & -40 & -60 & -80 & -100(\mathrm{~mm})\end{array}$
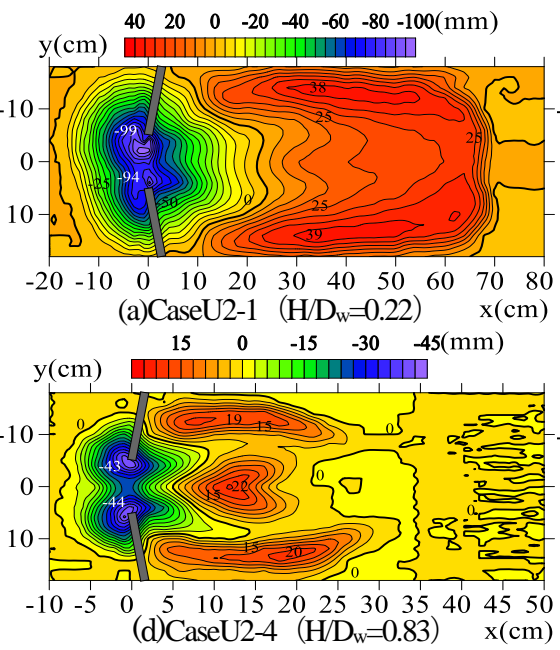

40

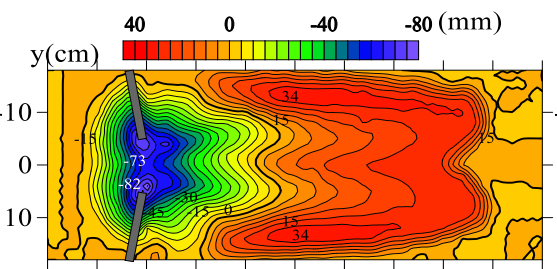

$\begin{array}{lllllllllll}-20 & -10 & 0 & 10 & 20 & 30 & 40 & 50 & 60 & 70 & 80\end{array}$ (a)CaseD2-1 $\quad\left(\mathrm{H} / \mathrm{D}_{\mathrm{w}}=0.22\right)$

$20 \quad 0 \quad-20 \quad-40(\mathrm{~mm})$

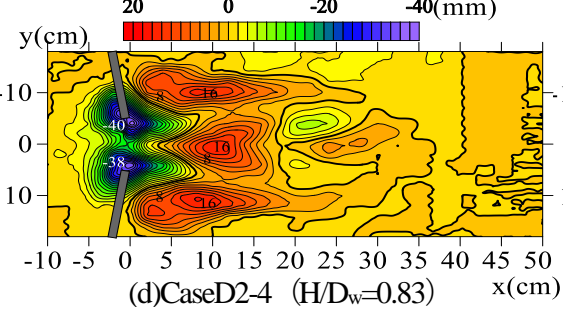

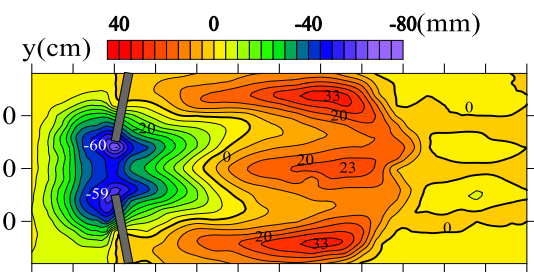

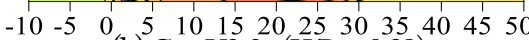
(b) CaseU2-2 $\left(\mathrm{H} / \mathrm{D}_{\mathrm{w}}=0.38\right) \quad \mathrm{x}(\mathrm{cm})$ $\begin{array}{lllllll}16 & 8 & 0 & -8 & -16 & -24 & -32(\mathrm{~mm})\end{array}$

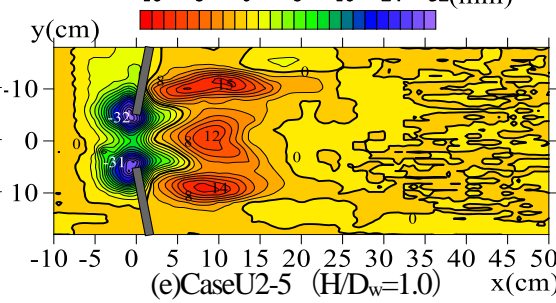

図-2 河床形状(上向き堰)

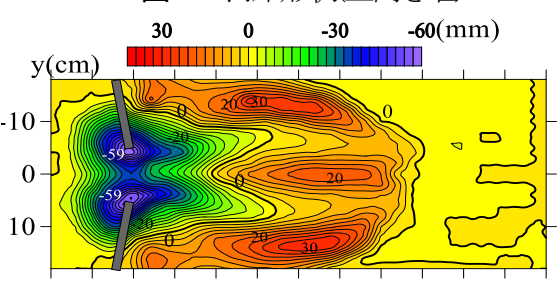

$\begin{array}{rllllllllllll}-10 & -5 & 0 & 5 & 10 & 15 & 20 & 25 & 30 & 35 & 40 & 45 & 50\end{array}$ (b)CaseD2-2 $\left(\mathrm{H} / \mathrm{D}_{\mathrm{w}}=0.38\right) \quad \mathrm{x}(\mathrm{cm})$ $15 \quad 0 \quad-15 \quad-30(\mathrm{~mm})$

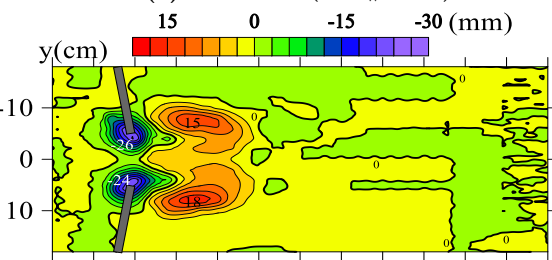

$\begin{array}{lllllllllllll}-10 & -5 & 0 & 5 & 10 & 15 & 20 & 25 & 30 & 35 & 40 & 45 & 50\end{array}$ (e)CaseD2-5 $\left(\mathrm{H} / \mathrm{D}_{\mathrm{w}}=1.0\right) \quad \mathrm{x}(\mathrm{cm})$

図-3 河床形状(下向き堰)

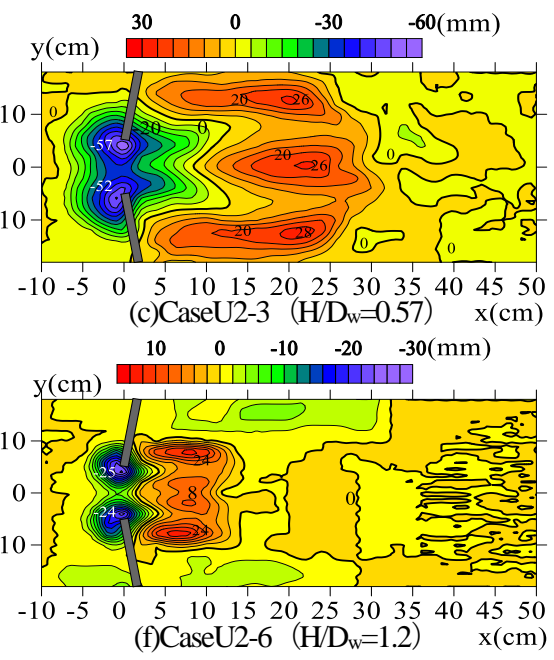

$\begin{array}{llllllll}20 & 10 & 0 & -10 & -20 & -30 & -40 & -50\end{array}(\mathrm{~mm})$

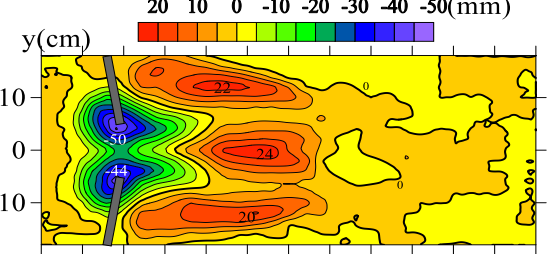

$\begin{array}{llllllllllllll}-10 & -5 & 0 & 5 & 10 & 15 & 20 & 25 & 30 & 35 & 40 & 45 & 50\end{array}$ (c)CaseD2-3 (H/D $=0.57) \quad \mathrm{x}(\mathrm{cm})$ ${ }_{10}^{(\mathrm{c}) \text { CaseD2-3 }} \underset{0}{\left(\mathrm{H} / \mathrm{D}_{\mathrm{w}}=0.57\right)}-10 \quad-20(\mathrm{~mm})$

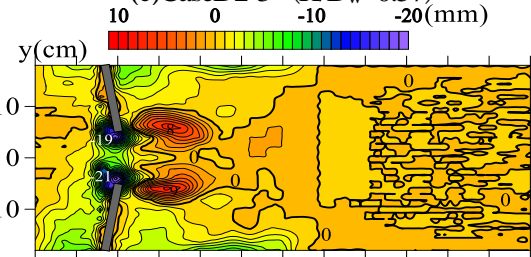

$\begin{array}{llllllllllllll}-10 & -5 & 0 & 5 & 10 & 15 & 20 & 25 & 30 & 35 & 40 & 45 & 50\end{array}$ (f)CaseD2-6 $\left(\mathrm{H} / \mathrm{D}_{\mathrm{w}}=1.2\right) \quad \mathrm{x}(\mathrm{cm})$

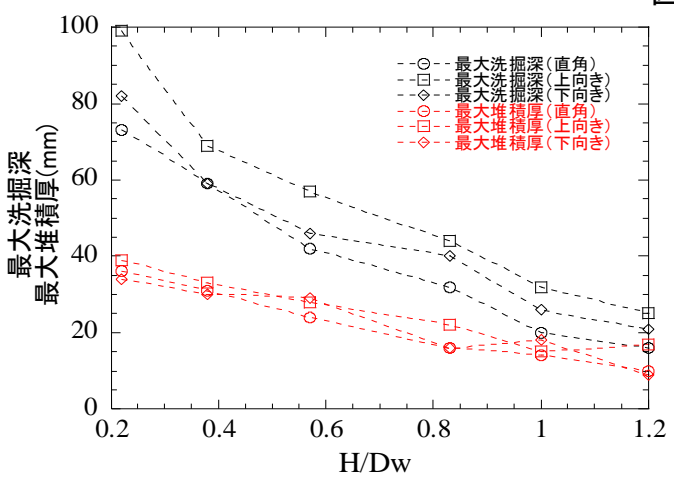

図-4 最大洗掘深・最大堆積厚と相対越流水深

下向き堰における顕著な砂州は，上向き堰のケースと同 様に水路中央およびその左右岸に沿って 3 箇所で発生し, 全般的には左右岸の砂州の高さが水路中央のそれに較べ て大きく，堆積形状は相対越流水深 $H / D_{\mathrm{w}}=0.38 \sim 0.83$ の範 囲で類似している．相対越流水深 $H / D_{\mathrm{W}}=1.0,1.2$ において は堰高が低く, 堰開口部周辺の主流速は小さいことから, 水路中央部の砂州は顕著に発達していない.

なお, Hey8)による Weirs/Dams, Deflectors および Vanes において発生する Pool(P)や Bar(B)の位置を図-5 に抜粋す る. 本実験結果では開口部を有する堰においては開口部下

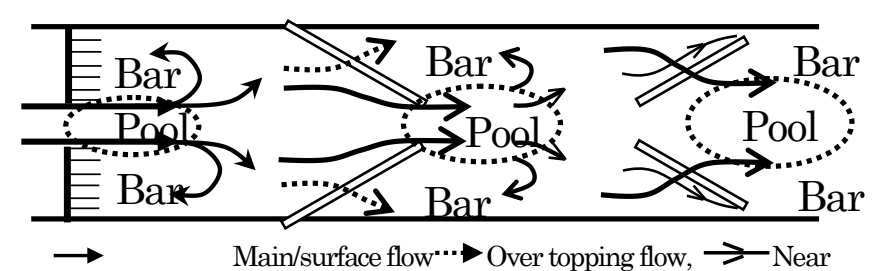

図-5 環境修復対策工（Hey1992 から抜粋）

流において砂州が発生したが彼等の洗掘, 堆積の概略図に はその砂州が示されていない. 砂粒レイノルズ数や無次元 掃流力の大きさに応じて河床変動に変化はあるものの開 口部下流において砂州が形成される可能性は高い.

相対越流水深 $H / D_{\mathrm{w}}$ に対する最大洗掘深および最大堆積 厚の変化を図-4に示す. 最大洗掘深および最大堆積厚は, 静的平衡河床においては上向き堰, 下向き堰および直角堰 の三者において相対越流水深 $H / D_{\mathrm{W}}$ の増大に伴って指数関 数的に減少する. 相対越流水深 $H / D_{\mathrm{W}}$ が増大するに従って, 堰開口部を通過する流量および流速が相対的に減少し，そ の結果として堰への接近流速, 堰先端の馬蹄形渦が弱まっ たことが示唆される. また, 三者の比較では最大堆積厚は, 類似しているが，上向き堰において若干，堆積厚が大きく なる傾向がある. 最大洗掘深は，上向き堰，下向き堰およ 
び直角堰の順で小さくなる.

\section{（2）堰開口部下流の局所流}

図-6および図-7 は，それぞれ，CaseU2-4 における水面 形および主流速のコンターを示寸. 水面高は, 堰から $3 \mathrm{~m}$ 上流の水路中央を基準水面に取り，それからの偏差を $\mathrm{mm}$ 単位で図中に示している. また，主流速のコンター図には 流線を実線で示した. 水面は，堰前面で堰上げ背水効果が 現れて高くなり堰下流では相対的に低い. 局所的には堰開 口部近傍で高く, 特に堰先端 $\mathrm{y}= \pm 5 \mathrm{~cm}$ の堰直下流より流 下方向に小さい領域がある.

直角堰では堰先端 $\mathrm{y}= \pm 5 \mathrm{~cm}$ の堰直上流で局所的に大き な值を示したが，上向き堰ではこの傾向は発生していない 表面流における高速域は，堰上流では $\mathrm{y}= \pm 15 \mathrm{~cm}$ である が流下方向に漸縮し， $\mathrm{x}=30 \mathrm{~cm}$ においては $\mathrm{y}= \pm 10 \mathrm{~cm}$ に狭 まり, さらにその下流では漸拡し $\mathrm{x}=70 \mathrm{~cm}$ においては $\mathrm{y}=$ $\pm 15 \mathrm{~cm}$ であることが認められる. 一方で堰下流の $\mathrm{x}=30 \mathrm{~cm}$ において両岸近傍では低速域が発達していることが分か る. 表面流の流線も $\mathrm{x}=0-30 \mathrm{~cm}$ の区間では水路中央部に収 束, $x>30 \mathrm{~cm}$ では発散する様子が見られる.

図-8〜10 は，それぞれ，水面下 $2 \mathrm{~cm}$ および $3.5 \mathrm{~cm}$ で計測 された, 主流速 $\mathrm{U}$, 二次流の横断方向成分 $\mathrm{V}$ および鉛直成 分 $\mathrm{W}$ の平面流況を示寸. なお, 堰頂部は基準水面下 $2.5 \mathrm{~cm}$ 位置にある.

水面下 $2 \mathrm{~cm}$ における主流速Uは, 堰上流側では堰直上流, 横断方向には開口部で大きな值を示し，堰下流側では断面 平均流速 $21.5 \mathrm{~cm} / \mathrm{s}$ より大きい $\mathrm{U}>22 \mathrm{~cm} / \mathrm{s}$ の高速域が流下方 向に漸縮する傾向を有する．また，堰直上・下流の流速は 越流の影響を受けて相対的に速い. 堰下流域の左右岸近傍 の低速域は $\mathrm{x}<30 \mathrm{~cm}$ の区間では流下方向に漸拡する傾向を 有する.

水面下 $3.5 \mathrm{~cm}$ の主流速は, $U>22 \mathrm{~cm} / \mathrm{s}$ の高速域が堰上流域 では堰開口部に向かって急縮・加速し，堰下流域では漸 拡・減速している. 左右岸近傍の低速域は急縮する傾向を 示寸. 水面下 $3.5 \mathrm{~cm}$ における主流速の空間分布は水面下 $2 \mathrm{~cm}$ のそれらとは異なり, 河床形状の影響を強く受けてい る.

なお，堰下流域の左右岸に発生した砂州上では低速域が 形成されている. また水路中央部の砂州上では開口部下流 域に当たり高速域ではあるが, $x=10-30 \mathrm{~cm}$ の区間で減速傾 向を示寸.

二次流の横断方向成分 $\mathrm{V}$ および鉛直成分 $\mathrm{W}$ は，水面下 $2 \mathrm{~cm}$ および $3.5 \mathrm{~cm}$ において強弱の違いはあるものの, 類似 の傾向を有する. 二次流の横断方向成分 $\mathrm{V}$ は, 堰上流域で は堰開口部に向から収束する流れで，堰直上流の $\mathrm{y}= \pm$ $5 \mathrm{~cm}$ で極大值を示すことが認められる. 堰下流域では堰直 下流では堰開口部に向から収束寸る流れ，堰下流に発達し た砂州上では峰部近傍では二次流の横断方向成分 V が発 散する流れ，砂州間の谷部において収束する流孔となって
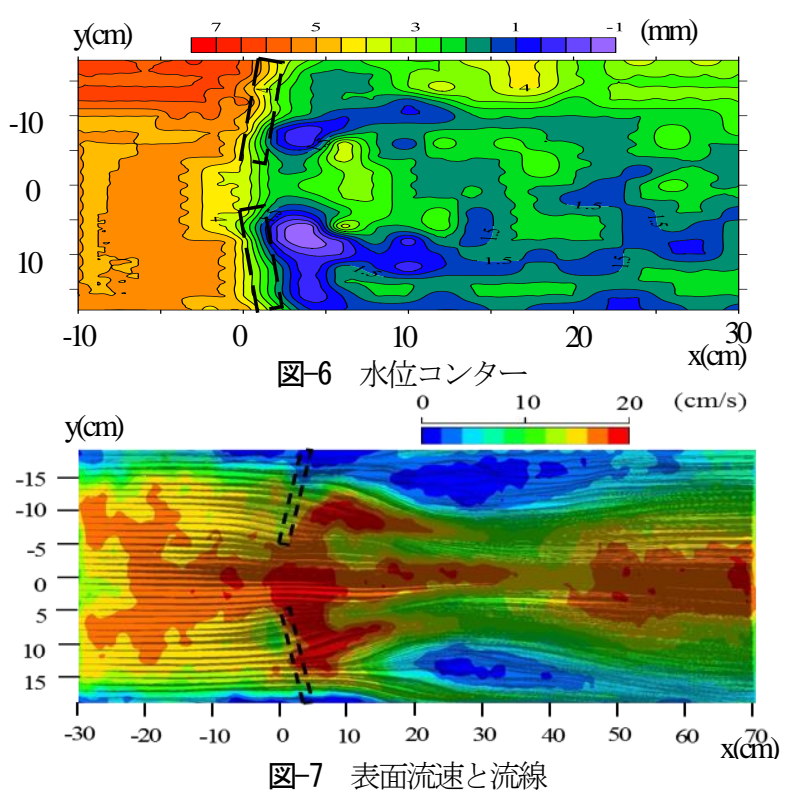

いることが認められる.

二次流の鉛直方向成分 $\mathrm{W}$ は, 堰下流域では砂州との位 置関係が強く, 砂州上では上昇流, 砂州間の谷部において 収束寸る下降流が認められ，水面下 $3.5 \mathrm{~cm}$ において明膫で ある.

図-11および 12 は，それぞれ，堰下流域の $\mathrm{x}=10 \mathrm{~cm}, 20 \mathrm{~cm}$ および $30 \mathrm{~cm}$ における二次流の鉛直方向成分Wおよび主流 速 U の鉛直面内のコンター図を示寸.

二次流の鉛直方向成分 $\mathrm{W}$ は，極めて規則性の高、空間 分布を示し, 上昇流は砂州の峰部に当たる水路中央 $\mathrm{y}=0 \mathrm{~cm}$ および $\mathrm{y}= \pm 13 \mathrm{~cm}$ 付近で, 下降流は砂州の中間の谷部に位 置する $\mathrm{y}=-9 \mathrm{~cm} \sim-4 \mathrm{~cm}$ および $\mathrm{y}=3 \mathrm{~cm} \sim 7 \mathrm{~cm}$ の区間で発生し ていることが認められる. 堰前面で発生した横断方向に軸 を持つ馬蹄形渦 ${ }^{3}$ は堰開口部を流下寸るに従って流下方向 に軸を持つ縦渦に向きを変え, その外側には逆回転の縦渦 が形成されたことが認められる. これらの縦渦は上昇流お よび下降流の大きさから， $\mathrm{x}=10 \mathrm{~cm}$ で最も強く流下に従つ て若干弱まっている.

主流速 U のコンター図中には, 図-9１1 を参考に二次 流セルを破線で示した. 主流速 U は, $\mathrm{x}=10 \mathrm{~cm}$ においては 堰開口部 $\mathrm{y}=-5 \mathrm{~cm} \sim 5 \mathrm{~cm}$ の区間では相対的に高速且つ横断 方向に一様であり, $\mathrm{y}<-5 \mathrm{~cm}$ および $\mathrm{y}>5 \mathrm{~cm}$ の区間では鉛直 方向に強いシアーがあり, 最大流速は流下方向に低下傾向 を示す. $\mathrm{x}=20 \mathrm{~cm}$ および $30 \mathrm{~cm}$ においては主流速の等值線が 水路中央 $\mathrm{y}=0 \mathrm{~cm}$ の底面付近で上に凸, $\mathrm{y}= \pm 5 \mathrm{~cm}$ 付近では 高速域が見られ，水路中央で上昇流および $\mathrm{y}= \pm 5 \mathrm{~cm}$ 付近 の下降流の影響を受けたことが推察される.

堰頂部を越流した $\mathrm{y}=-18 \mathrm{~cm} \sim-5 \mathrm{~cm}$ および $\mathrm{y}=5 \mathrm{~cm} \sim 18 \mathrm{~cm}$ の区間の主流速は，相対的に低速域に当たり， $\mathrm{x}=10 \mathrm{~cm}$ に おいては堰の影響を受けて鉛直方向に主流速の空間変化 は大きく強いせん断層が形成されているが，流下と共に鉛 直方向の変化は小さくなり横断方向の流速変化が顕著と 


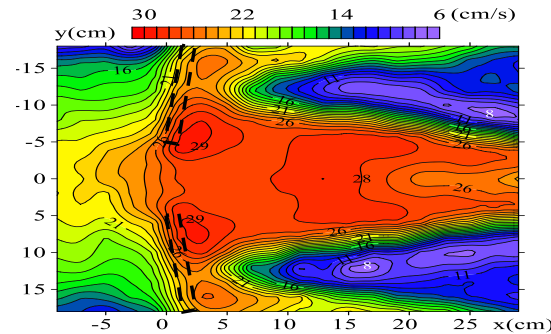

(a) 水面下 $2.0 \mathrm{~cm} \quad\left(H / \mathrm{D}_{\mathrm{w}}=0.83\right)$

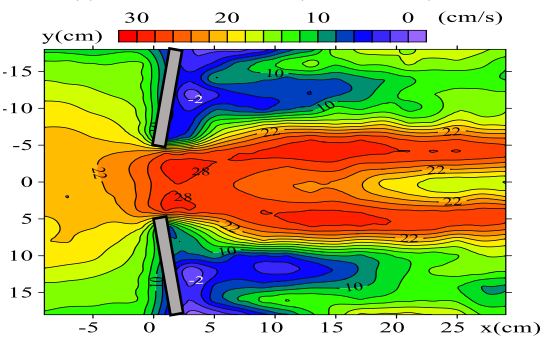

(b) 水面下 $3.5 \mathrm{~cm} \quad\left(H / \mathrm{D}_{\mathrm{w}}=0.83\right)$

図-8 主流速 U の平面コンター

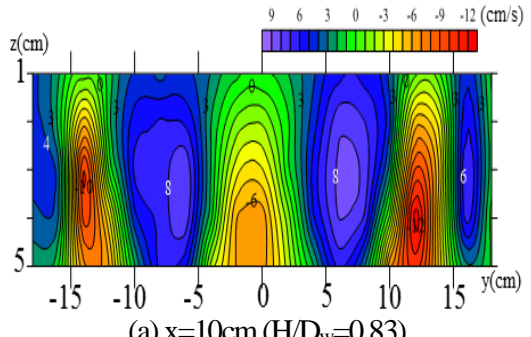

(a) $\mathrm{x}=10 \mathrm{~cm}\left(\mathrm{H} / \mathrm{D}_{\mathrm{w}}=0.83\right)$

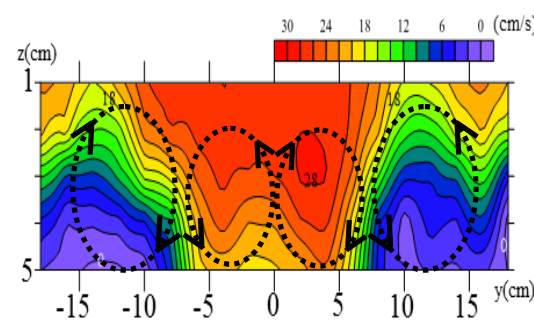

(a) $\mathrm{x}=10 \mathrm{~cm}\left(\mathrm{H} / \mathrm{D}_{\mathrm{w}}=0.83\right)$

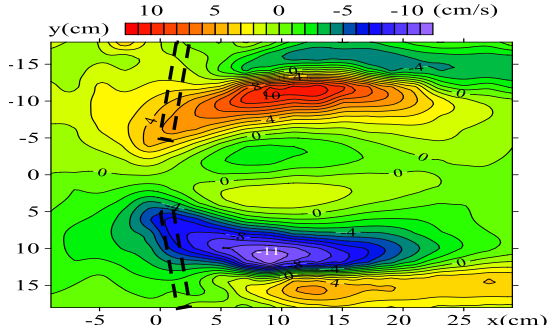

(a) 水面下 $2.0 \mathrm{~cm} \quad\left(H / \mathrm{D}_{\mathrm{w}}=0.83\right)$

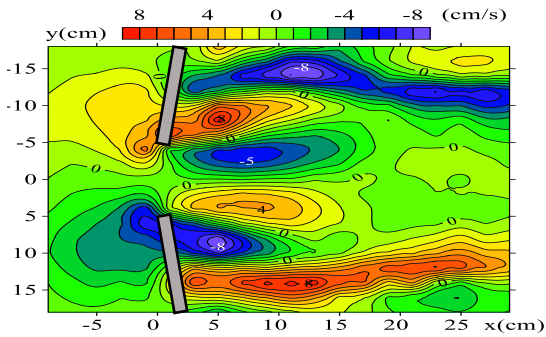

(b) 水面下 $3.5 \mathrm{~cm} \quad\left(\mathrm{H} / \mathrm{D}_{\mathrm{w}}=0.83\right)$

図-9 二次流 $\mathrm{V}$ の平面コンター

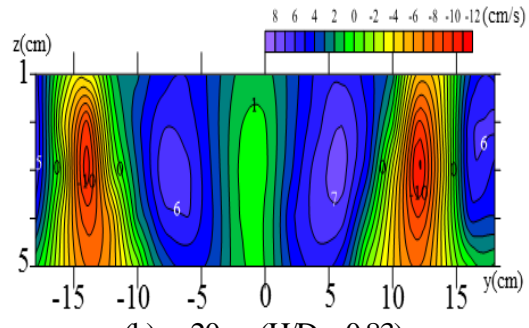

(b) $\mathrm{x}=20 \mathrm{~cm}\left(\mathrm{H} / \mathrm{D}_{\mathrm{w}}=0.83\right)$

図-11 二次流 $\mathrm{W}$ の鉛直面コンター

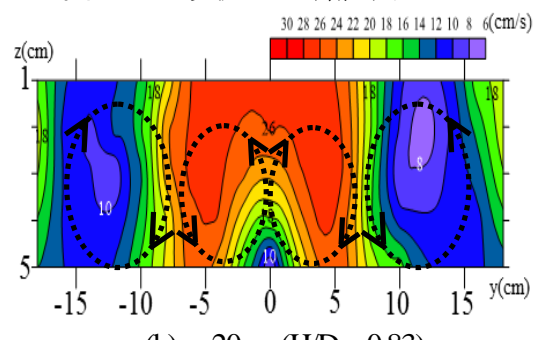

(b) $\mathrm{x}=20 \mathrm{~cm}\left(\mathrm{H} / \mathrm{D}_{\mathrm{w}}=0.83\right)$

図-12 主流速 U の鈆直面コンター

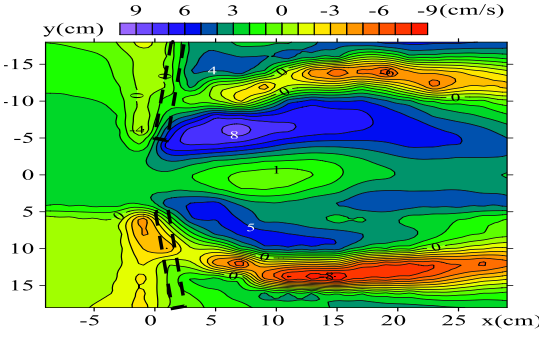

(a) 水面下 $2.0 \mathrm{~cm} \quad\left(H / D_{\mathrm{w}}=0.83\right)$

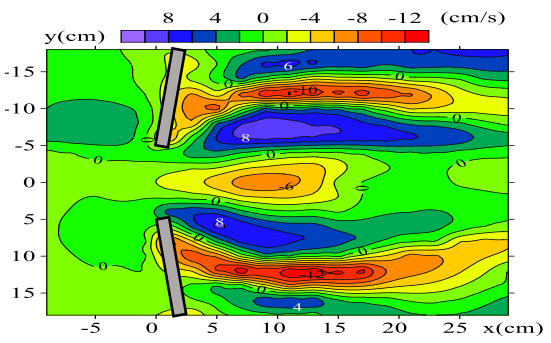

(b) 水面下 $3.5 \mathrm{~cm} \quad\left(H / \mathrm{D}_{\mathrm{w}}=0.83\right)$

図-10 二次流 W の平面コンター

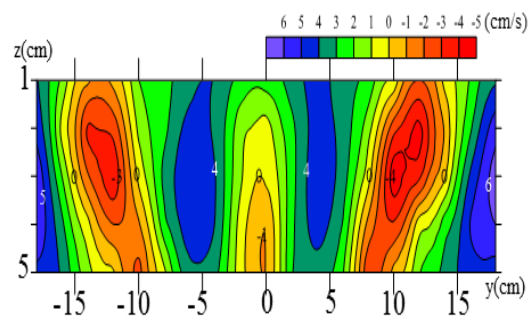

(c) $\mathrm{x}=30 \mathrm{~cm}\left(\mathrm{H} / \mathrm{D}_{\mathrm{w}}=0.83\right)$

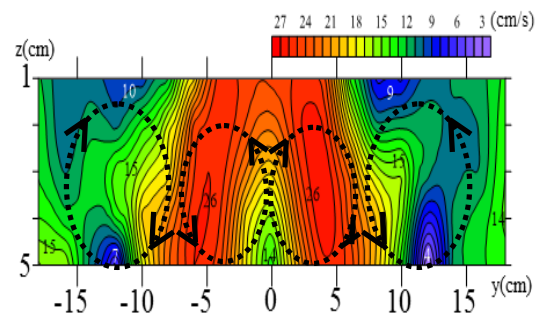

(c) $\mathrm{x}=30 \mathrm{~cm}\left(\mathrm{H} / \mathrm{D}_{\mathrm{w}}=0.83\right)$
なっている. 特に, $\mathrm{y}<-10 \mathrm{~cm}$ および $\mathrm{y}>10 \mathrm{~cm}$ の区間では水 面近傍で流速が流下に従って低下傾向を示寸。これは, 左 右岸の強い上昇流により底面付近の低速流体塊が水面付

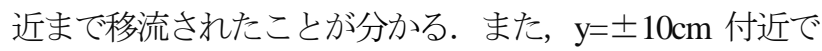
は流下に従って水面付近では減速傾向, 底面付近では若干 加速傾向にあり, $\mathrm{x}=30 \mathrm{~cm}$ においては僅かではあるが水面 に較心゙底面付近で流速が大きくなっているが注目される。 この点についても，らせん流に伴う二次流による運動量輸 送によって説明出来る.

（3）表面流の解析による上昇・下降流の同定 表面流における連続条件から，

$$
\frac{\partial W}{\partial z}=-\left(\frac{\partial U}{\partial x}+\frac{\partial V}{\partial y}\right)
$$

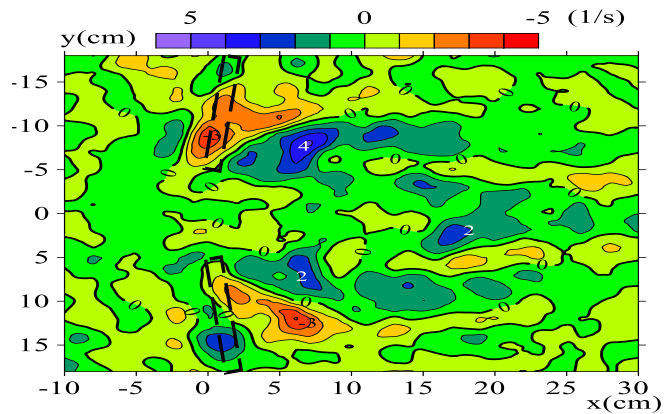

図-13 $-(\partial U / \partial x+\partial V / \partial y)$ (上向き堰)

となる. 水表面で $W=0$ を仮定すれば,

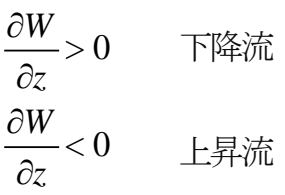


となる. 図-13 は，各々，上向き堰における表面流速の主 流方向成分 $U$ および横断方向成分の空間勾配から得られ る式(1)の右辺を表している. 表面流の解析によって得られ た上昇流位置は朱色で下降流位置は青色で表現されてい る. 図-13 より上昇流および下降流の発生位置は, 図-10 に示された水面下 $2 \mathrm{~cm}$ 位置の上昇流および下降流の発生 位置と類似していることが読み取れる.

\section{4. まとめ}

本研究では, 静的平衡河床を対象に上向き堰において開 口部を有する堰が下流の河床変動に与える影響および堰 下流域に発達した砂州上の流れの三次元性について検討 した. 得られた主要な結果は以下の通りである.

1) 上向き堰および下向き堰における洗掘は, 堰開口部周辺 に集中し, 洗掘の面的広がりおよび梁さは相対越流水深 の増加に従って小さくなる. また，上向き堰と下向き堰 との比較では洗掘の面的広がりは上向き堰の方が大きい 2) 最大洗掘深および最大堆積厚は, 静的平衡河床において は上向き堰，下向き堰および直角堰の三者において相対 越流水深の増大に伴って指数関数的に減少する. 三者の 比較では極大堆積厚は類似しているが，上向き堰におい て若干, 堆積厚が大きくなる傾向がある. 最大洗掘深は, 上向き堰，下向き堰および直角堰の順で小さくなる.

3) 上向き堰の下流域では砂州との位置関係が強く, 砂州上 では上昇流，砂州間の谷部において収束寸る下降流が認 められた。

4) 上向き堰前面で発生した横断方向に軸を持つ馬蹄形渦 は堰開口部を流下寸るに従って流下方向に軸を持つ縦 渦に向きを変え, その外側には逆回転の縦渦が形成され た.
5) 連続式を用いた表面流の解析による上昇・下降流の発生 領域について同定することが可能であることが示され た.

謝辞：本研究は, 平成 26 年度 -28 年度文部科学省科学研 究費補助金，基盤研究 C (課題番号：26420502）の援助の もとに実施された。ここに記して謝意を表します。

\section{参考文献}

1)ハインツ科学・経済・環境センター編, 青山己織訳：ダム撤去, 岩波書店, 2004

2)Rosgen, D.: The Cross-Vane, W-Weir and J-Hook Vane Structures...Their Description, Design and Application for Stream Stabilization and River Restoration., PROCEEDINGS of Wetlands Engineering \& River Restoration 2001 Edited by Donald F. Hays,: pp. 1-22. ,doi: 10.1061/40581(2001)72,2001

3) Guan, D., Melville, B., and Friedrich, H. :Flow Patterns and Turbulence Structures in a Scour Hole Downstream of a Submerged Weir., J. Hydraulic Engineering, Vol.140,No.1,pp.68-76.,2013.

4) Bruce W. Melville:Pier and Abutment Scour: Integrated Approach, J. Hydraulic Engineering, ASCE, Vol.123， No.2,,pp.125-136, 1997

5) Zhang H., Muto, Y., Nakagawa, H and Nakanishi, S.: Weir removal and its influence on hydro-morphological features of upstream channel, Journal of applied mechanics, Vol.15, No2, pp.591-599,2012.

6) 住田英之, 武藤裕則, 田村隆雄 : 堰の部分撤去に伴い上流側一 発達する流路の形状について, 土木学会論文集 B1（水工 学) Vol. 71, No. 4, I925-I930, 2015

7)大本照憲 ・吉田樹宏・宇根拓孝 : 越流堰の部分撤去が河 床変動および流れの構造に与える影響.土木学会論文集 B1(水工学) Vol.72, No.4, I_661-I_666, 2016.2

8)Hey RD: River mechanics and habitat creation,Fisheries in the year 2000,pp.271-285,Institute of Fisheries Management, Nottingham,UK,1992

(2016. 9.30 受付)

\section{EFFECTS OF UPWARD WEIR WITH AN OPENING ON RIVER BED AND FLOW STRUCTURE}

\section{Terunori OHMOTO and Hirotaka Une}

Scouring or depositing downstream of submerged weirs with an opening is a sediment phenomena resulting from the interaction of the three-dimensional turbulent flow field around the structure and the moveable sand bed. This paper presents the experimental study on the downstream channel bed due to weir with an opening, paying attention to the effects of relative overflow depth on local scouring around the structure, sand bars and three-dimensional flow patterns. The experiments were conducted under the clear-water scour condition for an equilibrium scour hole. The experimental results show that local scouring and sand bar development downstream of the submerged weirs decrease with relative overflow depth and turn out strongly paired cellular secondary currents. 